\title{
Atsinaujinančių energijos išteklių panaudojimo elektros energetikoje skatinimo priemonių modeliavimas ${ }^{1}$
}

\author{
Lina Sveklaitė, Andrius Stasiukynas \\ Mykolo Romerio universitetas \\ Ateities g. 20, LT-08303 Vilnius, Lietuva \\ doi:10.13165/VPA-14-13-2-06
}

\begin{abstract}
Anotacija. Atsinaujinančiu energijos ištekliu plètros politikai Europos Sajungoje dažniausiai naudojamos fiksuotu tarifų (feed-in-tariffs) ir žaliujų sertifikatu (tradable green certificates) skatinimo priemonès. Pastebima, kad tiek teoriniu, tiek praktiniu aspektu abi skatinimo priemonès turi trūkumu, kurie priverčia susidurti su iššükiais ne tik politika formuojančias ir igyvendinančias institucijas, tačiau ir padidina našta vartotojams. Pasakytina, kad skatinimo priemoniu taikymo sékmé dažniausiai priklauso nuo pasirinkto modelio, tad norint išvengti abieju sistemu trūkumu bütina apsvarstyti kita skatinimo modeli. Straipsnyje siekiama objektyviai ịvertinti pagrindiniu skatinimo priemoniu privalumus ir trūkumus. Apžvelgiamas praktinis skatinimo priemoniu naudojimas Europos Sajungos šalyse narèse.
\end{abstract}

Raktažodžiai: energetikos sektoriaus valdymas, elektros energetikos reguliavimas, atsinaujinantys energijos ištekliai, skatinimo priemonès, fiksuoti tarifai, žalieji sertifikatai.

Keywords: energy sector governance, regulatory framework of electricity, renewable energy sources, feed-in-tariffs, tradable green certificates.

\section{Ivadas}

Elektros energijos tiekimas dèl savo svarbos moderniam visuomenès gyvenimui ir nacionaliniam saugumui traktuojamas kaip visuomenès interesui svarbi viešoji paslauga, kuria turi pasirūpinti valstybè. Viešojo valdymo institucijos taikyda-

1 Straipsnyje pateiktos ịžvalgos nelaikytinos oficialia Valstybinės kainų ir energetikos kontrolès komisijos pozicija. 
mos ịvairias priemones siekia sureguliuoti energijos tiekimą, gamybą ir užtikrinti nacionalinių strateginių tikslų pasiekiamumą.

Atsinaujinančių energijos išteklių (AEI) panaudojimo didinimas energijos gamybos balanse susiduria su ịvairiais trukdžiais, kuriems ịveikti yra taikomos ịvairios skatinimo priemonès. Vis dèlto ambicingi kai kurių šalių tikslai elektros energijos vartojimą iš AEI iki 2020 m. padidinti tam tikru procentu gali turèti ir neigiamų pasekmių tiek elektros energijos vartotojams, tiek tolesnei AEI plètrai.

Šiuo metu gamyba iš AEI dažniausiai skatinama naudojant fiksuotą supirkimo tarifą, kuris remiamiems gamintojams taikomas 10-25 m. laikotarpiui, bei kvotų, žaliųjų sertifikatų, skatinimo priemones. Svarbu pažymėti, kad $2012 \mathrm{~m}$. dauguma Europos Sąjungos šalių narių, atsižvelgdamos ị 2009 m. balandžio 23 d. Europos Parlamento ir Tarybos direktyvą 2009/28/EB dèl skatinimo naudoti atsinaujinančių išteklių energiją, iš dalies keičiančią bei vèliau panaikinančią Direktyvas 2001/77/EB ir 2003/30/EB, numatančią technologijų plètojimo skatinamą bei visų rūšių technologijų naudojimą, neịvertinusios technologijų kainų mažèjimo didžiausią fiksuotą tarifą nustatė brangioms, tačiau neefektyvioms technologijoms. Tai, atpigus technologijoms, sukèlè investuotojų susidomėjimą, neribotą elektrinių steigimąsi, netikslingą lèšu panaudojimą, neracionalią bei fragmentuotą AEI sektoriaus plètrą bei pernelyg greitą ịrengtosios galios atitiktị nacionaliniams planiniams rodikliams.

Valstybèse, kuriose veikia fiksuotų tarifų paramos priemonè, AEI plètra prasideda tik nustačius pakankamai aukštą fiksuotą supirkimo tarifą, taip garantuojant investuotojams užtikrintą investicijų grąžą. Tačiau naudojant šią skatinimo priemonę susiduriama su padidejusia našta vartotojams ir AEI plètros pristabdymu dèl netinkamai nustaty to tarifo neefektyvioms ir brangioms technologijoms. Naudojant žaliųjų sertifikatų skatinimo priemonę pastebimas investuotojų pasyvumas dèl svyruojančių žaliųjų sertifikatų kainų ir neužtikrintumo dẻl investicijų grąžos. Žvelgiant i ES patirtị pastebèta, kad dažniausiai naudojamos skatinimo priemonès turi savų privalumų ir trūkumų.

Straipsnio tikslas - išanalizavus atsinaujinančių energijos išteklių panaudojimo elektros energetikoje skatinimo priemones, pasiūlyti optimalų modelį. Šiam tikslui pasiekti suformuluoti uždaviniai:

1. apžvelgti atsinaujinančių energijos išteklių panaudojimo elektros energetikoje dažniausiai taikomas skatinimo priemones bei išskirti jų privalumus ir trūkumus;

2. įvertinus dažniausiai naudojamų atsinaujinančių energijos išteklių elektros energetikoje skatinimo priemones, pasiūlyti optimalų skatinimo modelị.

Rengiant straipsnị taikyti dokumentų analizès, turinio analizės, genetinis bei alternatyvų ir kiti metodai. Atliktas empirinis tyrimas - ekspertų apklausa, kurio duomenys pateikiami integruotai kartu su literatūros analize. 


\section{Pagrindinių elektros energijos gamybos iš atsinaujinančių energijos išteklių skatinimo priemonių apžvalga}

Europos Sąjungos klimato kaitos ir energetikos paketas nenumato, kaip šalys narès turi skatinti AEI plètrą, tačiau šiuo metu yra platus AEI skatinimo politikos priemoniu pasirinkimas [1]. Pagrindines elektros energijos gamybos iš AEI skatinimo priemones galima priskirti Martinot et al. nagrinètoms dviem paradigmoms - senajai ir naujajai [12]. Pažymètina, kad naujajai paradigmai atstovauja fiksuotų tarifų skatinimo priemonè, kur skatinimo priemonès nukreipiamos į AEI technologijas, jų tobulinimą, tuo tarpu žaliụjų sertifikatų skatinimo priemonę galima priskirti naujajai paradigmai, kur pastebimos naujos tendencijos - vis didesné orientacija ị rinką (1 paveikslas).

AEI skatinimo paradigmų kaita sietina ir su Vakaruose XX a. devintajame dešimtmetyje vyravusia viešojo valdymo reforma (plačiai žinoma Naujosios viešosios vadybos (NVV) pavadinimu). Reformų įgyvendintojai puoselèjo liberalaus viešojo valdymo nuotaikas ir orientaciją i rinkos santykius, rezultatų ekonomizavimą bei kliento (vartotojo) pasitenkinimą teikiamomis paslaugomis.

\begin{tabular}{|c|c|c|}
\hline Senoji paradigma & $\longrightarrow$ & Naujoji paradigma \\
\hline Technologijų ịvertinimas & & Rinkos vertinimas \\
\hline Dėmesys įrangos tiekimui & $\rightarrow$ & $\begin{array}{l}\text { Dèmesys taikymui, pridètinei vertei } \\
\text { ir vartotojui }\end{array}$ \\
\hline $\begin{array}{l}\text { Ekonominis } \\
\text { igyvendinamumas }\end{array}$ & & $\begin{array}{l}\text { Politiniai, finansiniai, instituciniai ir } \\
\text { socialiniai poreikiai ir sprendimai }\end{array}$ \\
\hline Techninis demonstravimas & $\longrightarrow$ & $\begin{array}{l}\text { Verslo, finansinių, institucinių ir } \\
\text { socialinių modelių demonstravimas }\end{array}$ \\
\hline Rėmėjų „dovanos“ įrangai & $\longrightarrow$ & $\begin{array}{l}\text { Rėmejai dalijasi rizika ir išlaidomis } \\
\text { kurdami tvarią rinką }\end{array}$ \\
\hline Programos ir tikslai & $\longrightarrow$ & Patirtis, rezultatai ir pamokos \\
\hline
\end{tabular}

Šaltinis: [12]

1 pav. Skatinimo sistemos paradigmos

Martinot et al. teigia, kad senąja paradigma grịsta AEI plètra, orientuota $i$ technologijas, remtasi iki $2000 \mathrm{~m}$. Tuomet labiau buvo skatinama technologiju ivairove, demonstracijos. Nuo $2000 \mathrm{~m}$. pradejo vystytis naujoji paradigma, labiau orientuota ị rinką, kur daug dèmesio buvo skiriama politiniams, socialiniams bei finansiniams poreikiams. Taip pat buvo vertinama patirtis ir pasiekti rezultatai [12].

Fiksuoti tarifai. Europos Sajungoje plačiausiai praktikoje naudojama fiksuotų tarifų skatinimo priemonè. Hass et al. pastebi, kad ši paramos priemoné taikoma jau nuo $1980 \mathrm{~m}$. Pirmosios valstybès AEI skatinimui pradèjusios naudoti fiksuotų 
tarifų skatinimo priemonę buvo Vokietija, Danija ir Italija [5]. Šios skatinimo priemonès esmè ta, kad elektros energijos gamyba iš atsinaujinančių energijos ištekliu yra finansuojama iš kintančio antkainio (Lietuvoje ši dalis yra įtraukta ị viešuosius interesus atitinkančias paslaugas) visiems elektros energijos vartotojams, kuris yra nustatyto fiksuoto tarifo ir rinkos kainos skirtumas.

Taikant šią priemonę ilgam laikotarpiui nustatoma elektros supirkimo kaina, kurią AEI energijos gamintojams moka elektros skirstymo ar perdavimo bendrovès. Kaip rašoma Europos Komisijos komunikate „Parama elektros energijai iš atsinaujinančių energijos šaltinių gaminti“", pagrindiniai šios priemonès pranašumai yra tai, kad užtikrinamas investicijų saugumas investuotojams ir suteikiama galimybė koordinuoti bei diferencijuoti skirtingų technologijų rẻmimą. Tačiau taip pat pažymima, kad fiksuotų tarifų skatinimo priemonę sunku suderinti ES lygmeniu dèl nacionalinių rinkų principų, galima perteklinio finansavimo rizika, atsirandanti dèl technologijų kainų mažèjimo [4].

Paminètina, kad nors aukštas fiksuotas tarifas pritraukia investuotojus, tačiau kartu jis didina ir naštą vartotojui. Held et al. akcentuoja, kad ši priemoné tinka tuomet, kai norima skatinti konkrečias technologijas, tačiau joms atsipirkus būtinas ìkainio mažejjimo taikymas [6].

Jankauskas pažymi, kad nèra vienos fiksuoto supirkimo tarifo nustatymo sistemos. Priklausomai nuo šalies, fiksuotas tarifas gali būti nustatytas ịstatymuose ar poịstatyminiuose aktuose, taip pat ji gali nustatyti Reguliuotojas ar Vyriausybė [7]. Paminètina, kad dažniausiai tarifas diferencijuojamas atsižvelgiant ị technologiją (vejjo, saulès, biomasès elektrinèms) ir ịrengtosios galią, tačiau pasitaiko, kad tarifas yra nustatomas ir atsižvelgus ị elektrinių statybos vietą. Fiksuoti tarifai paprastai nustatomi 10-25 m. laikotarpiui, kas palengvina kredito gavimo sąlygas investuotojams, kadangi fiksuotas tarifas ir ilgas skatinamasis laikotarpis sumažina finansinę riziką. Paminètina, kad fiksuotas tarifas gali būti gaunamas ir skatinimo kvotų paskirstymo aukciono būdu. Paprastai aukcionų sistema naudojama didelio galingumo technologijoms.

Jankauskas pagrindiniams fiksuotų tarifų skatinimo priemonės pranašumams priskiria tai, kad:

- skatinamos įvairios technologijos nepriklausomai nuo investicijų ar įrengtosios galios;

- nustatoma aiški paramos struktūra;

- finansuojama ne iš šalies biudžeto;

- paprastas administravimas, jokių tiesioginių mokesčių;

- dalyvauja vietinis kapitalas [7]. Su šiuo teiginiu būtu galima nesutikti, kadangi, esant palankiai investicinei aplinkai ir laisvai rinkai, AEI skatinimo priemonès gali būti steigiamos ir naudojant užsienio kapitalą. Taip pat pažymètina, kad investicijos ị technologijas paprastai iš vietinès rinkos persikelia ị užsienio, kadangi kitur technologijų gamybos sąnaudos mažesnès, atitinkamai ir technologijų kaina patrauklesnè investuotojams. 
Tačiau ši sistema turi ir trūkumų:

- neveikia rinkos sąlygomis;

- neteisingai nustačius tarifą, parama AEI vartotojams tampa sunkia našta;

- nenustačius perskaičiavimo, ịvertinančio technologijų kaitą, duodami didžiuliai pelnai investuotojams;

- prievolè supirkti visą elektros energiją sukelia tinklų balansavimo problemas ir padidina tinklų sąnaudas.

Norint išvengti pasekmių, kurias atneštų technologijų kaita per ilgą laikotarpị, siūloma nustatyti digresijos koeficientą - fiksuoti tarifai kasmet mažinami ir naujiems ịrenginiams jie mažesni negu anksčiau įrengtiesiems [7, p. 80-81].

Tuo tarpu Europos energijos pardavejų federacija mato kur kas mažiau AEI pranašumų, akcentuodama tik tai, kad naudojant fiksuotų tarifų skatinimo mechanizmą investuotojai uždirba stabilias pajamas už kiekvieną ị tinklą patiektą megavatvalandę (MWh) ir kad ši priemonè skatina technologinę pažangą, kadangi skatina net ir neefektyvias technologijas. Tačiau trūkumų nurodoma kur kas daugiau:

- ribotos paskatos renkantis pigiausias technologijas;

- pakeitimai fiksuotų tarifų sistemoje dažnai turi ilgalaikių trikdžių atsižvelgiant ị technologinị vystymąsi, kas veda ị tokias situacijas, kai fiksuoti tarifai neatitinka technologinio tobulëjimo tempo;

- netinkama naudoti ten, kur gamyba iš AEI sudaro didelę dalį;

- fiksuoti tarifai mokami net ir tada, kai pagaminama elektros energija yra nereikalinga ir dèl ribotų eksporto galimybių negalima jos parduoti [3]. Kaip matyti, labiausiai akcentuojama tai, kad fiksuoti tarifai skatina visas technologijas, net ir nelabai efektyvias, o tai savo ruožtu skatina technologinị tobulèjimą, tačiau žiūrint iš kitos perspektyvos fiksuoti tarifai kartu ir stabdo naujų technologijų diegimą, kadangi neapibrěžti ar per maži fiksuoti tarifai gali atitolinti investicijas ị nauju technologijų paiešką ir plètojimą siekiant aukštesnès kokybės technologijų.

Tupy pastebi, kad fiksuotų tarifų schema turi daug ịvairių dizainų, tačiau visi dizainai turi bendrą charakteristiką:

- tinklo operatoriai yra ịpareigoti prijungti elektrines, energijos gamybai naudojančias AEI, ị tinklą;

- gamintojai iš AEI gauna fiksuotą tarifą už patiektą i tinklą kilovatvalandę $(\mathrm{kWh})$;

- fiksuotas tarifas mokamas nustatytą laikotarpi;

- tarifo suma paprastai nustatoma atsižvelgiant ị naudojamų AEI technologijų sąnaudas, metus, kuriais gamintojas pradèjo naudoti elektrinę, bei elektrinès ịrengtąją galią [16].

Kaip pastebi Leepa ir Unfried, būtent nuo fiksuotų tarifų skatinimo priemonès dizaino (reguliuojama iš AEI pagamintos elektros energijos apimtis, digresijos mokestis ir t. t.) priklauso jos sèkmè [11, p. 538].

Norint suprasti, kaip veikia fiksuotų tarifų skatinimo schema, būtina išnagrinèti 2 paveikslą. 


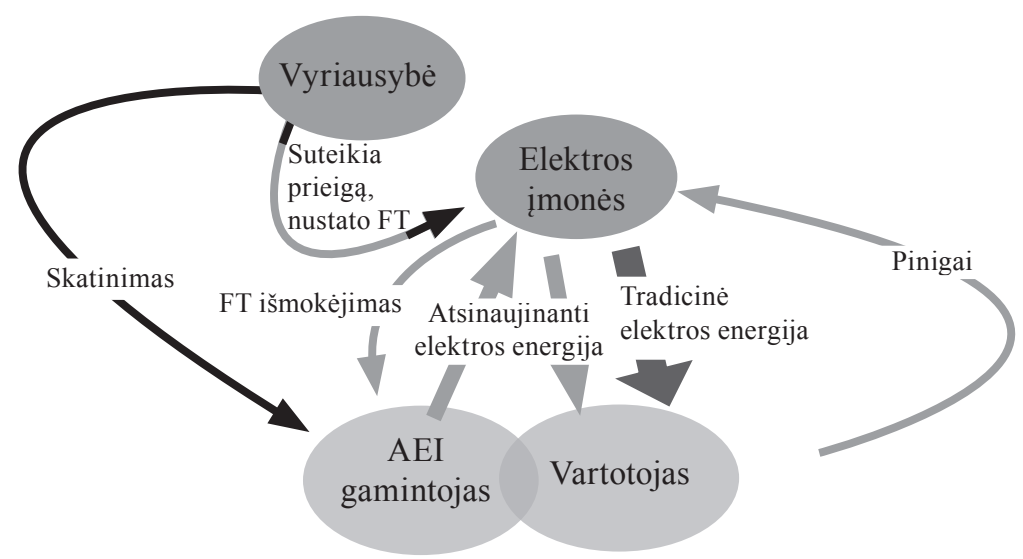

Šaltinis: [16]

2 pav. Fiksuotų tarifų skatinimo schema

Kaip matyti, vyriausybė arba jos paskirtos institucijos nustato AEI plètros skatinimo schemas bei ịpareigoja elektros įmones, tiksliau - tinklo operatorius, savo aptarnaujamoje zonoje 15-20 metų laikotarpiu suteikti prieigą prie tinklo bei supirkti visą elektros energiją, pagamintą iš AEI už nustatytą fiksuotą tarifą [15, p. 833].

Apibendrinant tai, kas išdėstyta, galima teigti, kad fiksuotų tarifų paramos sistema gali turèti daug dizainų, tačiau visiems jiems būdinga prijungimo prie tinklų pirmenybè, fiksuotas tarifas mokamas nustatytą laikotarpį. Ši paramos sistema patraukli investuotojams dèl savo nuspejjamumo ir stabilumo, tačiau nustačius per didelị tarifą ji gali didinti naštą vartotojams. Svarbu akcentuoti, kad fiksuotų tarifų skatinimo priemonè labiau tinka šalims, norinčioms kuo greičiau pasiekti nustatytus tikslus arba esančioms pradinėje AEI plètros stadijoje, kadangi, kaip jau minèta, aukštas paramos tarifas skatina steigti elektrines, elektros energijos gamybai naudojančias AEI, kas ir yra pagrindinis investuotojų rodiklis. Kalbant apie fiksuotų tarifų sistemą svarbu paminèti ir tai, kad šios sistemos įdiegimas nereikalauja didelių administracinių išlaidų.

Žalieji sertifikatai. Naujajai paradigmai atstovaujanti žaliųjų sertifikatų sistema labiau orientuota ị rinką. Pasak Currier, žalieji sertifikatai kaip reguliavimo mechanizmas užtikrina, kad tikslai būtų pasiekti ekonomiškai. Skirtingai nei fiksuoti tarifai, ši skatinimo priemone eliminuoja poreikị vyriausybei teikti tiesioginę paramą elektros energijos iš AEI gamintojams [2]. Elektros energijos sertifikatų paklausą kuria nustatytos kvotos, kurios yra išleidžiamos valstybès. Gamintojai sertifikatus gauna nemokamai, atsižvelgiant ị pagamintą elektros energijos kiekị. Paprastai 1 sertifikatas atitinka $1 \mathrm{MWh}$ pagamintos elektros energijos. Gamintojai toliau šiuos sertifikatus parduoda tiekejjams, o šie, savo ruožtu, galutiniams varto- 
tojams. Tiekejjas, be elektros energijos pardavimo rinkos kaina, gauna papildomų pajamų iš parduotų sertifikatų, kas leidžia pelningai investuoti į naujus elektros energijos iš AEI gamybos būdus [8].

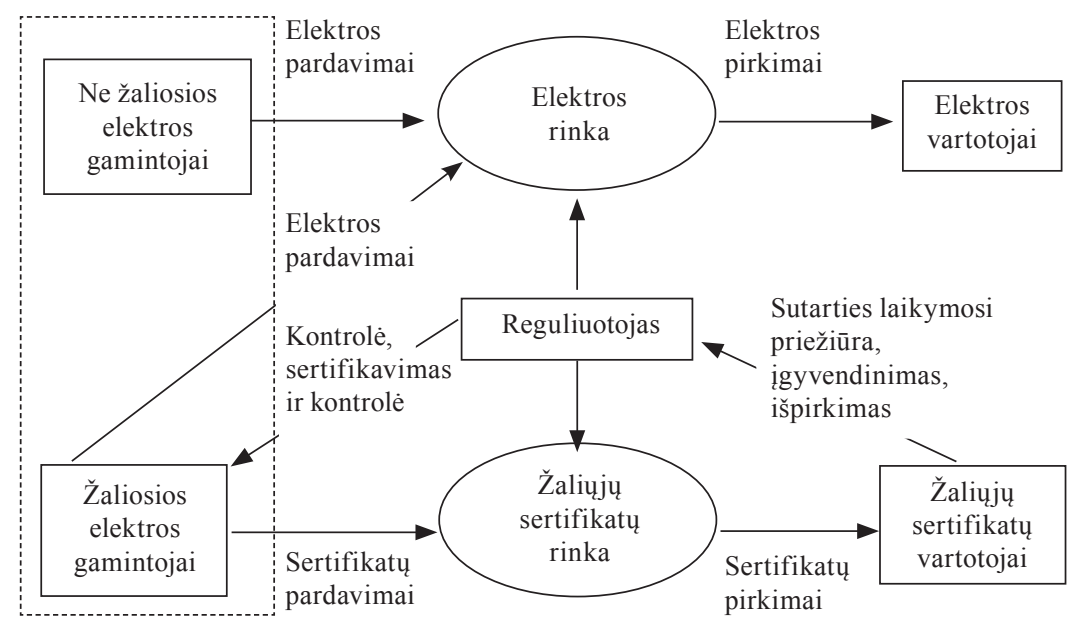

Šaltinis: $[8]$

3 pav. Žaliujų sertifikatų paramos schema

Kaip matyti 3 paveiksle, žaliųjų sertifikatų paramos schema kur kas sudètingesnè nei fiksuotų tarifų. Šios sistemos esmè ta, kad didmeniniai/mažmeniniai tiekejjai, skirstymo įmonès yra ịpareigojami tiekti (įsigyti) nustatytą procentinę dalị elektros energijos, pagamintos iš AEI. Igaliota institucija išleidžia žaliuosius sertifikatus, juos užregistruoja ir nemokamai išdalina gamintojams. Gamintojai, gaminantys elektros energiją iš AEI, gauna žaliųjų sertifikatų proporcingai pagamintam kiekiui. Gamintojai elektros energiją parduoda rinkoje rinkos kaina, o pelną gauna sertifikatų rinkoje parduodami turimus sertifikatus, kuriuos privalomai įsigyja elektros energijos tiekejjai, skirstymo įmonès. İsigyjamų žaliųjų sertifikatų kiekis kiekvienam tiekejui nustatomas kasmet proporcingai jo parduodamam elektros energijos kiekiui (pvz.: Švedijoje tiekejjai turi nusipirkti iki 3 proc. žaliųjų sertifikatų nuo bendro parduotos ir sunaudotos elektros energijos kiekio). Nustatytą dieną tiekejjai turi pateikti reikiamą skaičių žaliųjų sertifikatų, kad įrodytų, jog ịvykdẻ nustatytos procentinès dalies reikalavimą. Neįvykdęs savo įsipareigojimo tiekejjas moka baudą.

Vèjo elektrinių plètros galimybių studijoje pabréžiama, kad žaliųjų sertifikatų sistemą finansuoja visi elektros vartotojai, kadangi elektros tiekẻjai, ịsigiję nustatytą kiekị žaliujjų sertifikatų, patirtas sąnaudas paskirsto elektros energijos vartotojams [9]. 
Galima teigti, kad žaliojo sertifikato kaina - tai priemoka prie rinkos kainos už pagamintą/patiektą ,žaliosios“ elektros energijos vienetą, tačiau ši priemoka pasižymi nestabilumu ir gali kisti priklausomai nuo dalyvių skaičiaus sertifikatų rinkoje. Paminètina, kad naudojant žaliųjų sertifikatų skatinimo priemonę teoriniu požiūriu sukuriami 2 produktai: elektros energija, kuri parduodama elektros rinkoje, ir žalieji sertifikatai, kurie taip pat parduodami rinkoje.

Sertifikatų kaina yra nustatoma pagal jų kainą sertifikatų rinkoje (pvz., NordPool). İpareigojimai supirkti tam tikrą ,žaliosios“ elektros kiekị taikomi elektros tiekejjams ir susiejami su sankcijų (nuobaudos tarifų) sistema. Ji taikoma, kai tiekejjas ịpareigojimo neịvykdo [5].

Pažymètina, kad AEI skatinimas, grịstas žaliųjų sertifikatų skatinimo priemone, apima priverstini ịpareigojimą, kadangi iš anksto yra nustatomos paklausos ir pasiūlos sąlygos. Naudojant šią priemonę gamintojams, elektros energiją gaminantiems iš AEI, finansinè parama atsiranda tik pardavus žaliuosius sertifikatus (neįskaitant pajamų, gautų pardavus elektros energiją už rinkos kainą) [6].

Mokslininkai pastebi, kad sertifikatų rinka pasižymi dideliais žaliụjų sertifikatų kainų svyravimais, kuriuos sukelia ilgalaikès strategijos dẻl AEI nebuvimas. Taip pat, kaip ir taikant fiksuotų tarifų skatinimo priemonę, susiduriama su rizika, kad sertifikatų rinka bus atverta kitoms šalims, turinčioms kitus reguliavimo pagrindus [9, p. 43]. Aune et al. akcentuoja, kad žaliųjų sertifikatų paramos priemoné nėra geriausias politikos variantas siekiant nustatytų tikslų [1]. Vis dèlto pagrindinis privalumas būtų tas, kad naudojant šią skatinimo priemonę veikiama rinkos pagrindu, kadangi tiek elektros energija, tiek žalieji sertifikatai parduodami rinkos sąlygomis, tad vyksta minimalus valstybès įsikišimas leidžiant, prižiūrint ir registruojant sertifikatus.

Pasak Jaraminienės ir Siniak, „rinkos mechanizmo naudojimas padeda užtikrinti, kad žaliosios elektros galia būtų įdiegta ten, kur yra labiausiai efektyvu tai daryti, tuo būdu mažinant tikslų pasiekimo kainą“" [8, p. 56]. Vis dèlto kai kurie autoriai ị̌žvelgia ir trūkumų, pvz.: tai, kad naudojant šią skatinimo priemonę skatinamos tik konkurencingos technologijos, tačiau šis trūkumas gali būti išspręstas didinant sertifikatų skaičių mažiau konkurencingoms technologijoms [6]. V. Jankauskas taip pat kaip pagrindinị žaliụjų sertifikatų trūkumą ịvardija tai, kad ji remia tik pigiausias (nebūtinai geriausias) technologijas, neskatina jų plètros. Taip pat pastebi, kad mažiems elektros energijos tiekejjams gali būti labai sudètinga sekti rinką ir priimti efektyviausius sprendimus. Be to, nėra jokių priemonių, padedančių apsidrausti nuo kylančių sertifikatų kainų, kas suponuoja investuotojų neužtikrintumą ir aukštą elektros energijos kainą vartotojams [7].

Europos energijos pardavejjų federacija sukonkretina žaliųjų sertifikatų privalumus ir trūkumus:

- suteikia paskatą sumažinti išlaidas pasirenkant pigesnę, tačiau efektyvesnę technologiją;

- išvengiama neteisingos kainodaros; 
- suteikia galimybę prekiauti ne tik nacionalinèje rinkoje.

Pagrindiniai šios skatinimo priemonès trūkumai būtų tie, kad:

- sukuria neapibrèžtumą investuotojams dèl investicijų grąžos;

- paprastai investuotojai renkasi tik efektyviausias technologijas;

- kainodarą sertifikatų rinkoje nustato gamintojas, tad jei gamintojų skaičius nepakankamas, galima susidurti su aukšta žaliųjų sertifikatų kaina [3].

Pastebima, kad ilgu laikotarpiu nenumatytiems pelnams atsirasti trukdo gamintojai, investuojantys i pigesnes technologijas, taip priversdami dideles kainas sertifikatų rinkoje siūlančius gamintojus sumažinti kainas arba pasitraukti iš rinkos, kas turi įtakos sertifikatų kainos mažejimui. Taip sertifikatų rinkoje vyksta nuolatiné konkurencija, mažinanti elektros energijos kainą.

Apie 2000-uosius metus žalieji sertifikatai buvo laikomi moderniu paramos mechanizmu dèl to, kad veikè pagal rinkos principus. Tačiau ilgainiui paaiškejjo, kad abu paramos būdai iš dalies remiasi rinkos principu ir iš dalies politiniu mechanizmu (skatinančiojo tarifo mechanizmo atveju kaina nustatoma politikų, tačiau apimtis sureguliuoja rinka, tuo tarpu kvotinio mechanizmo atveju - kainas nustato rinka, bet kiekis nustatomas politiniu sprendimu [14, p. 66].

Vis dèlto pastebima, kad ši priemonè orientuota ị efektyvumą, kadangi investuotojai prieš rinkdamiesi ị kokią technologiją investuoti, turi atsižvelgti ị technologijos efektyvumo ir investicijų santykị, kad kuo greičiau pasiektų šios skatinimo priemonès nešamą naudą. Taip pat paminètina, kad ši priemonė skatina gamintojus rinktis kur kas palankesnes elektrinei vietas, t. y. arčiau tinklo, kas taip pat mažina išlaidas ir naštą elektros energijos vartotojui. Tad žalieji sertifikatai, nors ir reguliuojami vyriausybès, tačiau labiau priarteję prie rinkos nei fiksuoti tarifai.

Apibendrinant tai, kas išdėstyta, matyti, kad pagrindinès elektros energijos gamybos iš AEI skatinimo priemonès turi tiek pranašumų, tiek trūkumų (1 lentelè).

1 lentele. AEI skatinimo priemonių privalumai ir trūkumai

\begin{tabular}{|l|l|l|l|}
\hline \multicolumn{2}{|c|}{ REGULIUOJAMA KAINA } & \multicolumn{2}{c|}{ REGULIUOJAMAS KIEKIS } \\
\hline \multicolumn{2}{|c|}{ Fiksuoti tarifai } & \multicolumn{1}{c|}{ Trūkumai } & \multicolumn{1}{c|}{ Žalieji sertifikatai } \\
\hline \multicolumn{1}{|c|}{ Privalumai } \\
$\begin{array}{l}\text { Užtikrinta } \\
\text { investicijų grąža }\end{array}$ & $\begin{array}{l}\text { Perteklinio } \\
\text { finansavimo rizika }\end{array}$ & Orientuota ị rinką & $\begin{array}{l}\text { Neapibrěžtumas } \\
\text { investuotojams dèl } \\
\text { investicijų grąžos }\end{array}$ \\
\hline $\begin{array}{l}\text { Tinka šalims, } \\
\text { norinčioms kuo } \\
\text { greičiau pasiekti } \\
\text { nustatytus tikslus ar } \\
\text { esančioms pradinėje } \\
\text { AEI plètros stadijoje }\end{array}$ & $\begin{array}{l}\text { Sunku suderinti } \\
\text { tarptautiniu }\end{array}$ & $\begin{array}{l}\text { Galia diegiama ten, } \\
\text { kur yra labiausiai } \\
\text { lyektyvu }\end{array}$ & $\begin{array}{l}\text { Kintantiu žaliųu } \\
\text { sertifikatų kaina, } \\
\text { priklausanti nuo } \\
\text { dalyvių skaičiaus } \\
\text { sertifikatų rinkoje }\end{array}$ \\
\hline
\end{tabular}




\begin{tabular}{|c|c|c|c|}
\hline $\begin{array}{l}\text { Skatina } \\
\text { technologinę } \\
\text { pažangą }\end{array}$ & $\begin{array}{l}\text { Neveikia rinkos } \\
\text { sąlygomis }\end{array}$ & $\begin{array}{l}\text { Skatina rinktis } \\
\text { pigesnes, tačiau } \\
\text { efektyvesnes } \\
\text { technologijas }\end{array}$ & \\
\hline $\begin{array}{l}\text { Aiški paramos } \\
\text { struktūra }\end{array}$ & $\begin{array}{l}\text { Rizika, kad fiksuoti } \\
\text { tarifai neatitiks } \\
\text { technologinio } \\
\text { tobulejjimo tempo }\end{array}$ & $\begin{array}{l}\text { Tinkamesnė } \\
\text { sistema prekiaujant } \\
\text { tarptautineje rinkoje }\end{array}$ & \\
\hline \multirow[t]{3}{*}{$\begin{array}{l}\text { Nekintanti } \\
\text { supirkimo kaina }\end{array}$} & $\begin{array}{l}\text { Ribotos paskatos } \\
\text { renkantis pigiausias } \\
\text { technologijas }\end{array}$ & $\begin{array}{l}\text { Padeda išvengti } \\
\text { neteisingos } \\
\text { kainodaros }\end{array}$ & \\
\hline & $\begin{array}{l}\text { Netinka naudoti } \\
\text { ten, kur AEI sudaro } \\
\text { didelę rinkos dalị }\end{array}$ & & \\
\hline & $\begin{array}{l}\text { Fiksuoti tarifai } \\
\text { mokami net ir tada, } \\
\text { kai pagaminama } \\
\text { elektros energija yra } \\
\text { nereikalinga }\end{array}$ & & \\
\hline
\end{tabular}

Šaltinis: sudaryta autorių

Kaip matyti, fiksuotų tarifų ir priedų sistema pagal savo požymius priskiriama senajai paradigmai, kur daugiausia dėmesio skiriama technologijoms, kadangi dažnai aukščiausias tarifas nustatomas neefektyviausioms technologijoms, tačiau pastebima, kad tai skatina technologijų tobulèjimą, didesnị investuotojų susidoméjimą ir taip užtikrina AEI plètrą. Tuo tarpu žalieji sertifikatai priskiriami naujajai paradigmai, kur dominuoja politiniai, finansiniai, socialiniai kriterijai, kadangi ši priemonè kaip tik ir skatina mokestinès naštos mažejjimą elektros energijos vartotojui, didina konkurenciją tarp gamintojų dèl rinkos kaina parduodamos elektros energijos ir konkurencijos žaliųjų sertifikatų rinkoje. Žiūrint iš investuotojų perspektyvos, fiksuoti tarifai kelia didesni pasitikèjimą investuotojams, kadangi gaunama investicijų grąža yra nuspejjama ir stabili. Žaliųjų sertifikatų kaina rinkoje svyruoja, tad investuotojai susiduria su didesne rizika. Be to, paminètina, kad AEI fiksuotų tarifų sistema labiau tinka skatinti pažangą naujovių srityje, kadangi remia ne itin efektyvias AEI technologijas. Taip pat ji tinkama norint kuo greičiau pasiekti išsikeltus tikslus.

Žvelgiant ị AEI skatinimo praktiką matomi skatinimo priemonių trūkumai, su kuriais susiduria šalys narės naudodamos fiksuotų tarifų ir žaliųjų sertifikatų skatinimo priemones bei jiems mažinti pasirinktus mechanizmus. Vokietijoje siekiant išvengti perteklinio finansavimo rizikos, fiksuotiems tarifams taikomas kainos mažejjimo koeficientas kiekvienai technologijai, kas turèjo įtakos nuo $2013 \mathrm{~m}$. vèjo jègainių tarifo mažèjimui 1,5 proc, biodujų - 5 proc., biomasés - 1,5 proc., 
hidrojëgainių - 2 proc. Pasirinkta politika kartu mažina naštą ir elektros energijos vartotojams (M. Prantner, 2013). Čekijos Respublikai susidūrimas su pertekliniu saulès jègainių finansavimu inspiravo ịstatymo pakeitimą, išnaudotą nustatytą kvotą visoms technologijoms bei digresijos koeficiento ịvedimą. Pasak Energijos reguliavimo tarnybos (angl. Energy Regulatory Office) atsinaujinančiu energijos išteklių specialisto, fiksuotų tarifų skatinimo priemonè buvo pradèta naudoti todèl, kad reikejo iki $2010 \mathrm{~m}$. pasiekti nusistatytus tikslus, tad buvo daroma viskas, kad tikslai būtų pasiekti. Kai tikslas įvykdytas - parama sustabdyta.

Žvelgiant ị Ispanijos pavyzdį taip pat matyti fiksuotų tarifų sistemos netobulumas $-2008 \mathrm{~m}$. neapgalvotas politikos formavimas lèmé pernelyg aukštą fiksuotą supirkimo tarifą bei premijos dydị. Visa tai sukèlè deficitą elektros energijos sistemoje, kas, savo ruožtu, turejo įtakos įstatymo pakeitimui atgaline tvarka - pereita prie aukcionu grịstos skatinimo priemonès, sumažintas tarifas, nustatytos didelès administracinès kliūtys norint pradèti saulès energijos gamybos technologijų aukcioną, ịvesti papildomi prijungimo mokesčiai AEI gamintojams, nustatytas 7 proc. mokestis visai parduodamai elektros energijai, o naujų technologijų steigimasis nebeskatinamas. Visa tai padidino abejones dèl esamų AEI projektų. Taip pat padidino būsimas teisines pretenzijas prieš vyriausybės priemones, dar labiau susilpnino investicinę aplinką bei žymiai padidino politinę ir reguliavimo riziką. Pažymètina, kad fiksuoto tarifo paramos priemoné galiojo iki $2012 \mathrm{~m}$. Katalonų energetikos instituto (Institut Catala d'Energia) efektyvios energetikos ir atsinaujinančių energijos išteklių padalinio vadovė Morer akcentuoja, kad vienas iš pagrindinių šios sistemos trūkumų yra tai, kad ji neskatina technologijų tyrimų ir plètojimų vietinèje rinkoje, kadangi dauguma technologijų yra importuojamos.

Graikijoje AEI pletra skatinama fiksuotu tarifu. Taip pat investuotojai gali pasirinkti dotacijas ar papildomą fiksuoto tarifo didejjimą 15-20 proc., priklausomai nuo technologijos, ar mokesčių mažèjimą. Kaip pastebi Energetikos reguliavimo tarnybos ekspertas Vasilis, fiksuotų tarifų paramos priemonė tinka didinant pajègumus naujoje rinkoje ar skatinant mažiau subrendusių technologijų steigimąsi, tačiau čia taip pat kyla rizika pasirenkant netinkamą dizainą ar atliekant per mažą kainų pokyčių stebejjimą, kas suponuoja perteklinį finansavimą ir sukuria rinkos iškraipymus.

Lenkija jau nuo 2005 m. gamybos iš AEI skatinimui naudoja žaliụjų sertifikatų skatinimo mechanizmą, turẻdama tikslą palaipsniui skatinti žaliosios energijos paklausą ir sudaryti palankesnes sąlygas konkurencijai tarp žaliosios energijos gamintojų.

Žalioji energija iš gamintojų superkama vidutine visuotinai gaminamos elektros energijos rinkos kaina, kurios dydis nustatomas Lenkijos energetikos reguliavimo biuro URE (URE), o papildomos išlaidos kompensuojamos parduodant žaliuosius sertifikatus, kuriuos privalomai nuperka elektros energijos tiekejjas. Egzistuoja keli žaliųjų sertifikatų indekso būdai: OZEX_A indeksas, apimantis žaliuosius sertifikatus, kuriais prekiaujama biržoje, OZEN_A_TP indeksas, apimantis sertifikatus, kuriais prekiaujama ne biržoje pirmadieniais ir antradieniais, 
bei OZEN_A_POLPX sudètinis indeksas, apimantis prieš tai minètus indeksus (4 paveikslas).

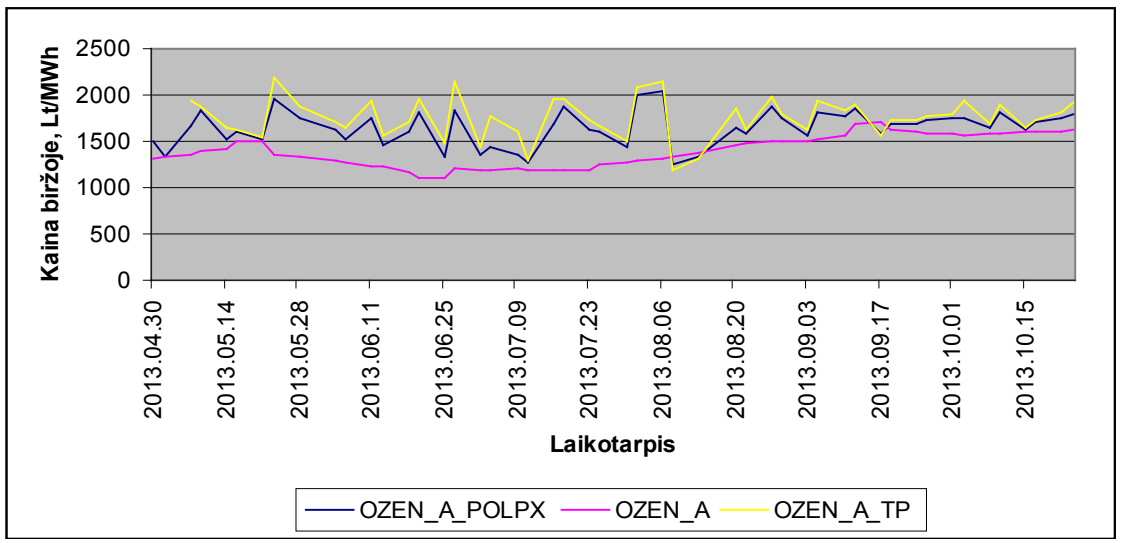

Šaltinis: sudaryta remiantis [10]

4 pav. Žaliųjų sertifikatų kainos 2013 m.

Kaip matyti 4 paveiksle, žaliųjų sertifikatų kainos yra didelès ir svyruoja kiekvieną mėnesị. Žemiausiomis kainomis sudaromi ne biržiniai sandoriai (kainos vidurkis $2013 \mathrm{~m}$. balandžio-spalio mėnesiai $1,4 \mathrm{Lt} / \mathrm{kWh}$ ), aukščiausiomis - perkama biržoje (kainos vidurkis $2013 \mathrm{~m}$. balandžio-spalio mėnesiai) $1,75 \mathrm{Lt} / \mathrm{kWh}$ ). Paminètina, kad Lenkijoje sertifikato kainos ribos nèra apibrèžtos teisiškai.

Svarbu paminèti, kad elektros energijos tiekejjai turi ir alternatyvą - vietoj žaliųjų sertifikatų įsigijimo jie gali mokèti pakaitinį mokestị (mokestis už kiekvieną elektros energijos MWh, kuris kasmet skelbiamas URE pirmininko). Paprastai pakaitinè suma atitinka tų metų maksimalią žaliųjų sertifikatų kainą. Tiekẻjai, neìvykdę jiems nustatytos kvotos ar nesumokèję pakaitinio mokesčio į Nacionalinị aplinkos apsaugos ir vandens valdymo fondą, moka URE tiems metams nustatytą baudą, kuri yra 1,3 karto didesnè už pakaitinị mokestį.

Pasak Lenkijos energetikos specialisto, ilgą laiką Lenkijos elektros rinka rodè nuolatinị AEI trūkumą. Tad reguliatoriaus nustatytas pakaitinis mokestis buvo pagrindinis veiksnys, lèmęs pajamas parduodant žaliuosius sertifikatus. Dèl šios priežasties sertifikatų kainą daugiau lemdavo reguliatorius nei rinka. Tačiau prognozuojama, kad laukiamas AEI dalies didejjimas ši jautrumą reguliavimui laikui bėgant mažins. Galima daryti prielaidą, kad žaliųjų sertifikatų sistema veiksmingai veikia tik esant pakankamam elektros energijos iš AEI gamintojų skaičiui, priešingu atveju sertifikatų sistema labiau primena Lietuvoje naudojamų fiksuotų tarifų principą. Tuo tarpu Rumunijoje naudojamas kitas žaliųjų sertifikatų skatinimo priemonès modelis, kai sertifikatų kiekis diferencijuojamas pagal technologijas. 
Nuo 2005 m. iki 2010 m. Rumunijoje, kaip ir Lenkijoje, galiojo taisyklè 1 sertifikatas už $1 \mathrm{MW}$ pagamintos elektros energijos. Stebint elektros energijos iš AEI gamintojų pasyvumą nuo $2010 \mathrm{~m}$. sertifikatų kiekis buvo diferencijuotas pagal technologijas:

Hidro- - 1 sertifikatas už $2 \mathrm{MW}$;

Vèjo - 2 sertifikatas už $1 \mathrm{MW}$;

Dujų - 1 sertifikatas už $1 \mathrm{MW}$;

Saulès -6 sertifikatai už 1 MW.

Tokie įstatymo pakeitimai turejjo ženklios įtakos AEI plètrai bei žaliųjų sertifikatų kainos mažèjimui (2 lentelè).

2 lentelè. Žaliujų sertifikatų kainos, Lt/MWh

\begin{tabular}{|l|c|c|c|c|c|c|c|c|c|c|c|c|}
\hline \multicolumn{10}{|c|}{$\mathbf{2 0 1 3}$} \\
\hline & $\mathbf{0 1}$ & $\mathbf{0 2}$ & $\mathbf{0 3}$ & $\mathbf{0 4}$ & $\mathbf{0 5}$ & $\mathbf{0 6}$ & $\mathbf{0 7}$ & $\mathbf{0 8}$ & $\mathbf{0 9}$ & $\mathbf{1 0}$ & $\mathbf{1 1}$ & $\mathbf{1 2}$ \\
\hline Sesija 2 & 189,9 & 185,6 & 153,8 & 130,8 & 134,6 & 137,7 & 137,5 & 139,2 & 141,1 & 189,9 & 150,7 & 153,8 \\
\hline Sesija 1 & 187,5 & 169,2 & 140,4 & 129,2 & 136,1 & 137,7 & 137,7 & 138,0 & 142,3 & 187,5 & 145,0 & - \\
\hline \multicolumn{10}{|c|}{$\mathbf{2 0 0 9}$} \\
\hline Sesija 2 & 670,2 & 189,9 & 189,9 & 189,9 & 189,9 & 189,9 & 189,9 & 189,9 & 189,9 & 189,9 & 189,9 & 189,9 \\
\hline
\end{tabular}

Šaltinis: [13]

Kaip matyti 2 lentelèje, 2009 m. žaliųjų sertifikatų kainos vidurkis sudarè 430,3 Lt/MWh. Nuo 2013 m. pastebimas kainų mažèjimas. Kainos vidurkis tesudarè 151,97 Lt/MWh, t. y. žaliųjų sertifikatų kaina sumažèjo apie 65 proc. 5 paveiksle matyti veiksniai, turèję įtakos kainų mažejjimui.

Centralized Green Certificates Market results

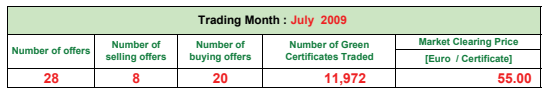

Centralized Green Cerifificates Market
July 2009

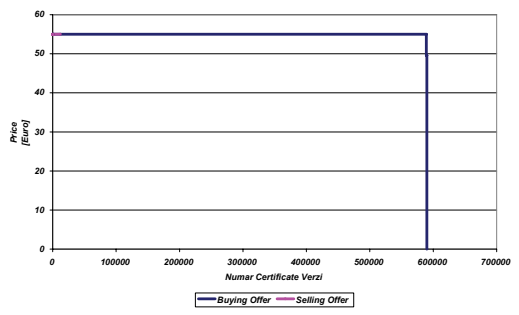

Centralized Green Certificates Market results

\begin{tabular}{|c|c|c|c|c|}
\hline \multicolumn{5}{|c|}{ Trading Month : July 2013 Trading Session 2} \\
\cline { 5 - 6 } Number of offers & $\begin{array}{c}\text { Number of } \\
\text { selling offers }\end{array}$ & $\begin{array}{c}\text { Number of } \\
\text { buying offers }\end{array}$ & $\begin{array}{c}\text { Number of Green } \\
\text { Certificates Traded }\end{array}$ & Market Clearing Price \\
\hline 85 & 71 & 14 & 227,054 & 39.87 \\
\hline
\end{tabular}

Centrelized Green Certificates Market
July 2013, Trading Session 2

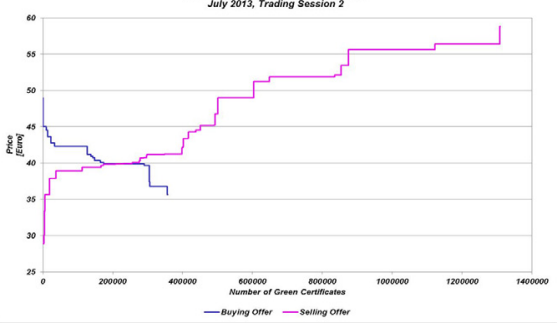

Šaltinis: [13]

5 pav. Centralizuotos žaliụjų sertifikatų rinkos rezultatai 
Kaip matyti dešinejje pusejje esančiame paveiksle, sertifikatų rinkoje padidejjus dalyvių skaičiui prasidejjo konkurencija, todèl sumažèjo sertifikatų kaina. Parduodamų pasiūlymų skaičius padidejo beveik 9 kartus, atitinkamai pasikeitė ir perkamų pasiūlymų skaičius. Žaliųjų sertifikatų skaičius rinkoje taip pat padidejo nuo 11,972 (2009 m.) iki 227,057 (2013 m.). Galima daryti prielaidą, kad, kaip ir buvo minèta teorinèje dalyje, žaliųjų sertifikatų kaina rinkoje priklauso nuo dalyvių skaičiaus - kuo daugiau dalyvių, tuo didesnè konkurencija, tuo mažesnè žaliụjų sertifikatų kaina.

\section{Pagrindinių elektros energijos gamybos iš atsinaujinančių energijos išteklių skatinimo priemonių tobulinimo galimybès}

Remiantis vertinimo dalyje pateiktais rezultatais apie pagrindinių skatinimo priemonių taikymo privalumus bei trūkumus, darytina išvada, kad nèra optimalaus skatinimo priemonès varianto. Tačiau galima daryti prielaidą, kad išsprendus pakankamo gamintojų skaičiaus, kuriančio konkurenciją sertifikatų rinkoje, problemą žaliųjų sertifikatų skatinimo priemonè atitiktų mažiausios naštos vartotojams kriterijų bei veiktų rinkos sąlygomis.

Pasakytina, kad fiksuotų tarifų paramos sistema yra patraukli investuotojams dèl garantuotos investicijų grąžos, tačiau ši sistema reikalauja nuolatinio rinkos stebejjimo norint išvengti perteklinio finansavimo nustačius aukštą supirkimo tarifą.

Turint omenyje, kad abi sistemos turi tiek pranašumų, tiek trūkumų, vertinga būtų pagalvoti apie kitą paramos modelị (6 paveikslas).

Atsižvelgiant ị valstybés galimybes bei pajëgumus teikti paramą elektros energijos iš AEI gamintojams nustatomas XY paramos laikotarpis. Nustatomas pagrịstas dalies investicijų atsipirkimo laikotarpis, $\mathrm{X}$ metų, kuriam, atsižvelgiant ị savikainą lemiančius veiksnius, tokius kaip: investicijų kaina, finansavimo kaina, atsipirkimo laikas, elektrinès galios išnaudojimo lygis, eksploatacijos kaina, išlaidos kurui bei pajamos, nustatomas fiksuotas tarifas, mokamas gamintojui. Pasibaigus X metų laikotarpiui pereinama prie žaliųjų sertifikatų sistemos. Ivykdžius šias sąlygas galima daryti prielaidą, kad bus pakankamas skaičius dalyvių veiksmingam sertifikatų rinkos veikimui. Be to, didesnè tikimybè, kad gamintojai galès lanksčiau laviruoti rinkoje, kadangi investicijos ị gamybą jau bus iš dalies atsipirkusios. Fiksuotų tarifų sistema patrauklesnè investuotojams dèl savo stabilumo, todèl ji turètų būti taikoma paramos pradžioje, prieš atsiperkant daliai investicijų. 


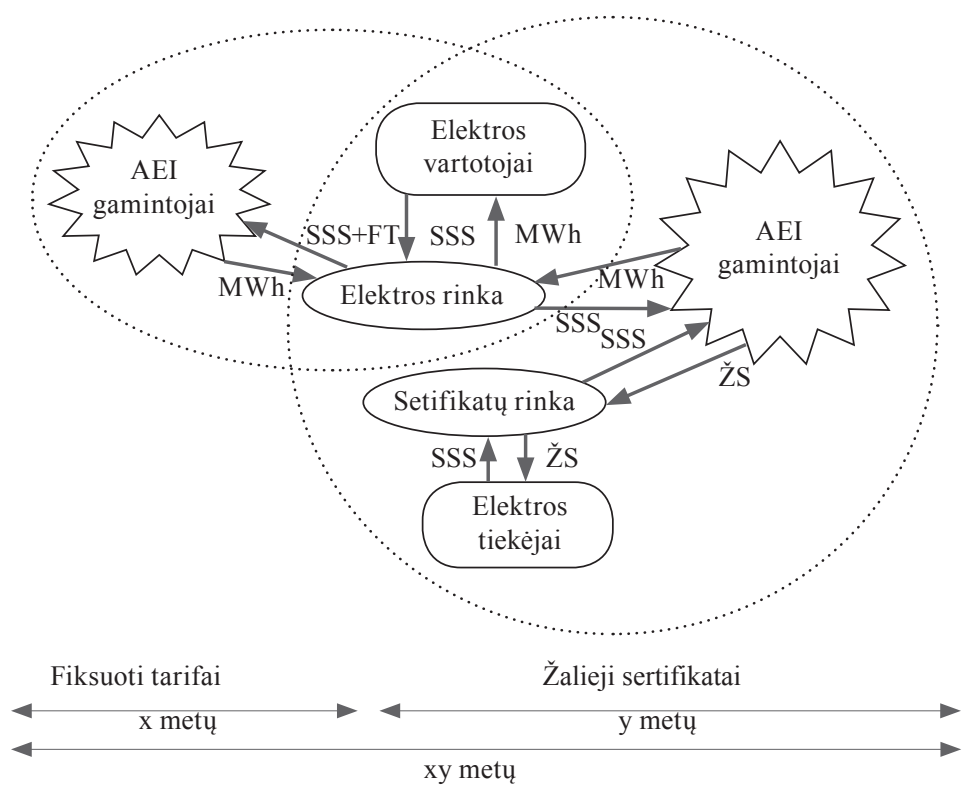

Šaltinis: sudaryta autorès

6 pav. AEI skatinimo modelis

\section{Išvados}

1. Išnagrinèjus atsinaujinančių energijos išteklių panaudojimo skatinimo elektros energijos gamybai pagrindines priemones ir kaitos tendencijas, galima teigti, kad:

- AEI skatinimo paradigmų kaita sietina su Naujosios viešosios vadybos (NVV) ideologijos sklaida bei NVV principu perkèlimu ị energetikos sektoriaus viešąji valdymą;

- fiksuotas tarifas, nors ir patrauklus investuotojams, tačiau skatina neefektyvias technologijas, pasikeitus technologijų kainai rinkoje inspiruoja perteklinị finansavimą, o nustatyta skatinimo kvota, siekiant apsaugoti viešąji interesą, stabdo AEI plètrą;

- žaliųjų sertifikatų skatinimo priemonès pagrindinis trūkumas tas, kad nesant pakankamam gamintojų skaičiui sertifikatų rinkoje ši skatinimo priemoné dažniausiai veikia panašiai kaip fiksuoti tarifai, kadangi elektros energijos tiekèjai, norẻdami ịvykdyti nustatytus ịsipareigojimus, iš AEI gamintojų ịsigyti nustatytą kiekị žaliųjų sertifikatų, dèl nepakankamo gamintojų skaičiau privalo rinktis pakaitinị mokestị, paprastai lygų aukščiausiai metinei žaliųjų sertifikatų kainai. Šios priemonès efektyvus veikimas pastebimas esant pakankamam gamintojų skaičiui, 
sudarančiam konkurencines sąlygas. Tokiu būdu sertifikatų rinkoje matoma kainų mažejjimo tendencija, kas savo ruožtu mažina ir naštą elektros energijos vartotojams.

2. İvertinus dažniausiai naudojamų skatinimo priemonių privalumus bei trūkumus sudarytas AEI skatinimo modelis, apimantis fiksuotų tarifų ir žaliụjų sertifikatų skatinimo mechanizmus; šio modelio dẻka išvengiama minètų priemonių trūkumų. Modelio išskirtinumas yra tas, kad nustatytą skatinamąjị laikotarpi paeiliui naudojamos šios dvi skatinimo priemonès: skatinamojo laikotarpio pradžioje nustatytas fiksuotas tarifas skatina naujų elektrinių steigimąsi, o tai turi ịtakos pakankamo gamintojų skaičiaus atsiradimui, konkurencijai žaliujjų sertifikatų rinkoje sudaryti, likusią skatinamojo laikotarpio dalị naudojant žaliųjų sertifikatų paramos priemonę. Skatinamuoju laikotarpiu fiksuotų tarifų skatinimo priemonę pakeitus žaliaisiais sertifikatais išvengiama perteklinio finansavimo rizikos bei sukuriamos sąlygos gamintojams veikti konkurencinėmis sąlygomis.

\section{Literatūra}

1. Aune, R. F. et al. Implementing the EU renewable target through green certificate markets. Energy Economics, 2012, No. 34, 992-993.

2. Currier, M. K. A regulatory adjustment process for the determination of the optimal percentage requirement in an electricity market with Tradable Green Certificates. Energy Policy, 2012, No. 34.

3. European Federation of Energy Traders. Effective integration of renewable energy in the European power market. EFET Position Paper, 2010.

4. Europos Komisijos komunikatas. Parama elektros energijai iš atsinaujinančių energijos šaltinių gaminti, 2005.

5. Hass, R. et al. A historical review of promotion strategies for electricity from renewable energy sources in EU countries. Renewable and Sustainable Energy Reviews. Vienna: Vienna University of Technology, 2011, No. 15(2011)1003-1034, p. 1011.

6. Held, A. et al. On the success of policy strategies for the promotion of electricity from renewable energy sources in the EU. Vienna: Vienna University of Technology, 2006.

7. Jankauskas, V. Atsinaujinančių energijos išteklių rẻmimo klaidos. Energetika, 2011, Nr. 2. http://www.lmaleidykla.lt/ojs/index.php/energetika/article/download/2063/954 [žiūrèta 2013-11-08].

8. Jaraminienè, E.; Siniak, N. Atsinaujinančių energijos išteklių panaudojimo elektros energijos gamyboje apimčių analizè ir rekomendacijų dèl elektros energijos, kuriai gaminti naudojami atsinaujinantys energijos ištekliai, gamybos ir supirkimo skatinimo 2010-2020 m. parengimas, 2008, 56. http://www.lvea.lt/public/gallery/C_ Documents\%20and\%20Settings_Aiste_Local\%20Settings_Application\%20Data_ Opera_Opera_profile_cache4_opr077B7.pdf

9. Lietuvos energetikos institutas. Vèjo elektrinių plètros galimybių analizè, 2009.

10. Polish power exchange. http://www.polpx.pl/en [žiūrèta 2013-11-08].

11. Leepa, C.; Unfried, M. Effects of a cut-off in feed-in tariffs on photovoltaic capacity: Evidence from Germany. Energy Policy, 2013, No. 56, 538. 
12. Martinot, E. et al. Renewable Energy Markets in Developing Countries. Washington, 2002, 311 .

13. Romanian gas and electricity market operator. http://www.opcom.ro/tranzactii_rezultate/ tranzactii_rezultate.php?lang=en\&id= [žiūrèta 2013-11-08].

14. Stasiukynas, A. Atsinaujinančių energijos išteklių naudojimo skatinimo elektros energetikoje analizè. Jaunuju mokslininku darbai, 2011, Nr. 1 (30), p. 66. http://vddb. library.1t/fedora/get/LT-eLABa-0001:J.04 2011 ISSN_1648-8776.N_1_30.PG_5562/DS.002.0.01.ARTIC [žiūrèta 2013-05-10].

15. Sukki, F. M. et al. Revised feed-in tariff for solarphotovoltaic in the United Kingdom: A cloudy future ahead? Energy Policy, 2013, No. 52, 833.

16. Tupy, T. The importance ot the Legal and Regulatory Framework of the Development of Renewable Energy. 2009.

\title{
Lina Sveklaitè, Andrius Stasiukynas
}

\section{The Possibilities of Electricity Produced from Renewable Energy Sources Support Schemes}

\begin{abstract}
Feed in tariffs and tradable green certificates are the main support schemes, which are used for renewable energy development in the European Union. It is to be noted that both support schemes have limitations, which associate challenges not only in the policy making and implementing institutions, but also by increasing the burden for consumers. The success of support schemes depend on the chosen model. So, in order to avoid the disadvantages of both support schemes, it is necessary to consider another support model. The article aims at objectively assessing the key disadvantages of the main support schemes.
\end{abstract}

Lina Sveklaité - Valstybinės kainų ir energetikos kontrolès komisijos Dujų ir elektros departamento Atsinaujinančių išteklių skyriaus vyr. specialistė, socialinių mokslų magistrè.

E. paštas: sveklaite@gmail.com

Andrius Stasiukynas - Mykolo Romerio universiteto Politikos ir vadybos fakulteto Viešojo administravimo instituto docentas, socialinių mokslų daktaras.

E. paštas: stasiukynas@mruni.eu

Lina Sveklaite, Master of Social Sciences, National Commission for Energy Control and Prices, Gas and Electricity Department, Renewable Resources Division, Chief specialist.

E-mail: sveklaite@gmail.com

The insight provided in the article is not to be considered as an official position of the National Commission for Energy Control and Prices.

Andrius Stasiukynas, Doctor of Social Sciences, Mykolas Romeris University, Institute of Public Administration, Assoc. Prof.

E-mail: stasiukynas@mruni.eu

Straipsnis įteiktas redakcijai $2014 \mathrm{~m}$. balandžio 18 d.; recenzuotas; parengtas spaudai $2014 \mathrm{~m}$. gegužès $24 \mathrm{~d}$. 